\title{
LIGHT MICROSCOPIC AUTORADIOGRAPHIC LOCALIZATION OF $\mu$ AND $\delta$ OPIOID BINDING SITES IN THE MOUSE CENTRAL NERVOUS SYSTEM ${ }^{1}$
}

\author{
ANDREA S. MOSKOWITZ*,2 AND ROBERT R. GOODMAN $\ddagger^{3}$ \\ * Neuroscience Program, Brain Research Institute, University of California, Los Angeles, California 90024 and $\$$ Departments of \\ Neuroscience and of Pharmacology and Experimental Therapeutics, The Johns Hopkins University, Baltimore, Maryland 21205
}

Received August 30, 1983; Revised November 22, 1983; Accepted November 23, 1983

\begin{abstract}
Much work has been done on opioid systems in the rat CNS. Although the mouse is widely used in pharmacological studies of opioid action, little has been done to characterize opioid systems in this species. In the present study the distribution of $\mu$ and $\delta$ opioid binding sites in the mouse CNS was examined using a quantitative in vitro autoradiography procedure. Tritiated dihydromorphine was used to visualize $\mu$ sites and $\left[{ }^{3} \mathrm{H}-d-\mathrm{Ala}^{2}-d-\mathrm{Leu}^{5}\right]$ enkephalin with a low concentration of morphine was used to visualize $\delta$ sites.

$\mu$ and $\delta$ site localizations in the mouse are very similar to those previously described in the rat (Goodman, R. R., S. H. Snyder, M. J. Kuhar, and W. S. Young, III (1980) Proc. Natl. Acad. Sci. U. S. A. 77:6239-6243), with certain exceptions and additions. $\mu$ and $\delta$ sites were observed in sensory processing areas, limbic system, extrapyramidal motor system, and cranial parasympathetic system. Differential distributions of $\mu$ and $\delta$ sites were noted in many areas. $\mu$ sites were prominent in laminae I, IV, and VI of the neocortex, in patches in the striatum, and in the ventral pallidum, nucleus accumbens, medial and midline thalamic nuclei, medial habenular nucleus, interpeduncular nucleus, and laminae I and II of the spinal cord. In contrast, $\delta$ sites were prominent in all laminae of the neocortex, olfactory tubercle, diffusely throughout the striatum, and in the basal, lateral, and cortical nuclei of the amygdala. 'The determination of the differential distributions of opioid binding sites should prove useful in suggesting anatomical substrates for the actions of opiates and opioids.
\end{abstract}

In 1973 high affinity, stereospecific opiate binding was demonstrated in rat brain homogenates (Pert and Snyder, 1973; Simon et al., 1973; Terenius, 1973) leading to the subsequent isolation and sequencing of the endogenous opioid peptides methionine (Met)- and leucine (Leu)-enkephalin (Hughes, 1975; Hughes et al., 1975; Pasternak et al., 1975a; Simantov and Snyder, 1976) and

${ }^{1}$ A. S. M. was supported by Mental Health Training Grant MH15345. R. R. G. was supported by Medical Scientist Training Grant MH-0053. This work was supported by National Institutes of Health Grant NS 07628, United States Public Health Service Grants DA 00266 and $\mathrm{MH} 00053$, and by a gift from the Brotman Foundation. We wish to thank Drs. M. J. Kuhar, S. H. Snyder, and J. C. Liebeskind for the use of equipment and for their comments concerning the experimental design and the manuscript. We wish to thank Linda Hester and Naomi Taylor for technical assistance. A preliminary report of these results has been presented (Goodman et al., 1982).

${ }^{2}$ To whom correspondence should be addressed.

${ }^{3}$ Present address: Department of Neurology, Memorial Sloan-Kettering Cancer Center, 1275 York Avenue, New York, NY 10021. $\beta$-endorphin (Li and Chung, 1976). Since that time much work has been done to define the characteristics and distribution of opioid binding.

Initially only one population of binding sites was thought to exist, but subsequent work has suggested several types. On the basis of pharmacological profiles of a variety of opiates, in the spinal dog, Martin et al. (1976) first proposed the existence of three sites, $\mu, \kappa$, and $\sigma$. Other sites, including $\delta$ and $\epsilon$, have since been proposed on the basis of studies using endogenous opioids and their analogues. A large amount of work has dealt with $\mu$ and $\delta$ sites. These two populations were initially suggested by bioassays of the guinea pig ileum and mouse vas deferens as well as data on binding to brain homogenates (Lord et al., 1977). The $\mu$ site has a much higher affinity for opiate alkaloids, whereas the $\delta$ site has a slightly higher affinity for enkephalins. Further evidence for the existence of $\mu$ and $\delta$ sites comes from protection experiments using phenoxybenzamine to inactivate $\mu$ and $\delta$ sites selectively (Robson and Kosterlitz, 1979), and 
from the demonstration of selective tolerance to $\mu$ and $\delta$ site agonists in the mouse vas deferens (Schulz et al., $1980,1981)$. In addition, $\mu$ and $\delta$ sites are differentially distributed within the CNS (Della Bella et al., 1978; Chang et al., 1979; Leslie et al., 1980; Lewis et al., 1981). According to pharmacological studies, $\mu$ sites mediate the analgesic effects of opioids (Herz et al., 1978) and $\delta$ sites their epileptic (Urca et a., 1977; Frenk et al., 1978) and rewarding (Stein and Belluzzi, 1979) effects.

Opioid binding sites are found in the CNS of a wide variety of vertebrates (Pert et al., 1974). Site distribution in the mammalian CNS has been extensively studied using in vivo autoradiography techniques (Kuhar et al., 1973; Pert et al., 1975, 1976; Atweh and Kuhar, 1977a, b, c; Pearson et al., 1980). Binding sites have been visualized in sensory processing areas, the limbic, extrapyramidal motor, and cranial parasympathetic systems. Recently developed in vitro autoradiography techniques (Young and Kuhar, 1979; Herkenham and Pert, 1980) also reveal the distribution of opiate binding sites in the CNS. Such techniques have several advantages over in vivo methods. They permit the use of ligands that penetrate the CNS poorly; they assure homogeneous exposure of all brain areas to the ligand; they allow adjacent sections incubated with labeled ligand plus a saturating concentration of cold ligand to serve as blanks; and they permit the visualization of different binding site types on adjacent sections. The latter advantage has facilitated comparing the distribution of $\mu$ and $\delta$ opioid binding sites in the rat CNS (Goodman et al., 1980; Duka et al., 1981a, b).

This study examined the distribution of $\mu$ and $\delta$ sites in the mouse CNS using the in vitro autoradiography technique of Young and Kuhar (1979). Pharmacological data suggest that the mouse and rat differ in their endogenous opioid systems. For example, morphine increases motor activity in mice (Carroll and Sharpe, 1972) but decreases it in rats (Kuschinsky and Hornykiewicz, 1974). Naloxone depresses food intake in the rat but not in the mouse (Holtzman, 1974). Recent work also shows species differences in the distribution of enkephalin immunoreactivity in the CNS (A. S. Moskowitz, J. C. Liebeskind, and L. L. Butcher, unpublished data).

\section{Materials and Methods}

Subjects. Female mice used were 10 to 15 weeks of age, of the C57BL/6BY strain (Jackson Laboratories).

Ligands. Tritiated dihydromorphine (DHM) (72 to 90 $\mathrm{Ci} / \mathrm{mmol}$ ) and $\left[{ }^{3} \mathrm{H}-d-A l a^{2}-d-\mathrm{Leu}^{5}\right]$ enkephalin (DADL) ( $32 \mathrm{Ci} / \mathrm{mmol}$ ) were obtained from New England Nuclear Corporation (NEN). DADL was donated by Dr. K. -J. Chang (Wellcome Research Laboratories).

Biochemical experiments. Brain homogenate experiments followed the procedure of Pasternak et al. (1975b). For on-the-slide biochemistry experiments, the procedure described below for autoradiography was modified as follows. Each slide held two $10-\mu \mathrm{m}$ sections from the rostral striatum. The striatum was chosen because it contains a high amount of both $\mu$ and $\delta$ binding (Chang et al., 1979; Goodman et al., 1980). After the final wash sequence, sections were wiped off the slide using What- man GF/B filters, which were placed in scintillation vials; $10 \mathrm{ml}$ of scintillation fluor (NEN 709) were added, vials were shaken for $1 \mathrm{hr}$, and counts were made.

All biochemistry experiments were performed in triplicate. For saturation experiments, 0.2 to $8.0 \mathrm{nM}\left[{ }^{3} \mathrm{H}\right]-$ DADL or 0.4 to $9.0 \mathrm{nM}\left[{ }^{3} \mathrm{H}\right] \mathrm{DHM}$ was used. DHM, at low concentrations, is selective for $\mu$ sites (Gillan et al., 1980). DADL binds to both $\delta$ and $\mu$ sites, although at low concentrations the majority $(70 \%)$ of its binding is to $\delta$ sites (Wolozin and Pasternak, 1981). For competition experiments, $\left.4.5 \mathrm{nM}{ }^{3} \mathrm{H}\right] \mathrm{DADL}+0.1$ to $300 \mathrm{nM}$ morphine hydrochloride was used. In each experiment a set of tissue aliquots or sections was incubated with ${ }^{3} \mathrm{H}$ ligand $+1.0 \mu \mathrm{M}$ levallorphan in order to determine nonstereospecific binding.

Autoradiography experiments. The procedure of Young and Kuhar (1979) was followed as outlined below. Mice were perfused via the left atrium with $50 \mathrm{ml}$ of ice-cold 0.05 M PBS, $\mathrm{pH} 7.4$, containing $0.1 \%$ formaldehyde. The brain and upper cervical spinal cord were removed, blocked, embedded in brain paste on a cryostat chuck, and frozen in dry ice snow. The tissue was stored at $-70^{\circ} \mathrm{C}$, and $8-\mu \mathrm{m}$ sections were cut at $-20^{\circ} \mathrm{C}$ using a Harris cryostat. Sections (one section per slide) were thaw-mounted onto room temperature slides coated with chrom alum-gelatin (subbed) and were stored for at least 2 weeks at $-20^{\circ} \mathrm{C}$ in order to minimize tissue loss during processing.

All of the following steps were performed at room remperature, unless otherwise indicated. Slides were placed on a warmer $\left(25\right.$ to $\left.30^{\circ} \mathrm{C}\right)$ for $30 \mathrm{sec}$, pre-incubated in $0.17 \mathrm{mM}$ Tris- $\mathrm{HCl}$ (Sigma) at $\mathrm{pH} 7.7$ containing 50 $\mu \mathrm{M}$ GTP and $100 \mathrm{mM} \mathrm{NaCl}$ (to remove endogenous opioid peptides) for $15 \mathrm{~min}$, and then immersed in $0.17 \mathrm{mM}$ Tris- $\mathrm{HCl}, \mathrm{pH} 7.7$, for $5 \mathrm{~min}$ (to wash out GTP and $\mathrm{NaCl}$ ). Adjacent sections were then incubated for $40 \mathrm{~min}$ in Tris buffer containing one of the following: $4.5 \mathrm{~nm}\left[{ }^{3} \mathrm{H}\right]$ DADL; $4.5 \mathrm{nM}\left[{ }^{3} \mathrm{H}\right] \mathrm{DADL}+1.0 \mu \mathrm{M}$ levallorphan; $4.5 \mathrm{nM}$ $\left[{ }^{3} \mathrm{H}\right] \mathrm{DADL}+2.5 \mathrm{nM}$ morphine; $1.7 \mathrm{nM}\left[{ }^{3} \mathrm{H}\right] \mathrm{DHM} ; 1.7$ $n M\left[{ }^{3} \mathrm{H}\right] \mathrm{DHM}+1.0 \mu \mathrm{M}$ levallorphan. Sections incubated with $1.7 \mathrm{nM}\left[{ }^{3} \mathrm{H}\right] \mathrm{DHM}$ were used to visualize $\mu$ sites, and sections incubated with $4.5 \mathrm{nM}\left[{ }^{3} \mathrm{H}\right] \mathrm{DHM}+2.5 \mathrm{nM}$ morphine were used to visualize $\delta$ sites. The rationale for using these conditions will be presented under "Discussion." An additional adjacent section was stained with thionin in order to identify anatomical areas. Slides were then dipped once in ice-cold Tris buffer, immersed twice (5 min each) in ice-cold Tris buffer, and dipped once in ice-cold distilled water. They were placed on an ice-cold tray, dried with a stream of ice-cold dry air, and stored at $4^{\circ} \mathrm{C}$ with desiccant (Drierite capsules, Driaire Inc.). They were then apposed to emulsion (Kodak NTB)coated, acid-cleaned coverslips (Corning no. 0) using Teflon chips and bulldog clamps and were placed in airtight boxes containing desiccant (Drierite chips). The exposure time was 14 to 15 weeks at $4^{\circ} \mathrm{C}$. Slides were developed using Kodak Dektol developer and were counterstained with Pyronin Y.

Sections were examined using an Olympus microscope equipped with a darkfield condenser, and anatomical areas were identified using the atlas of Sidman et al. 


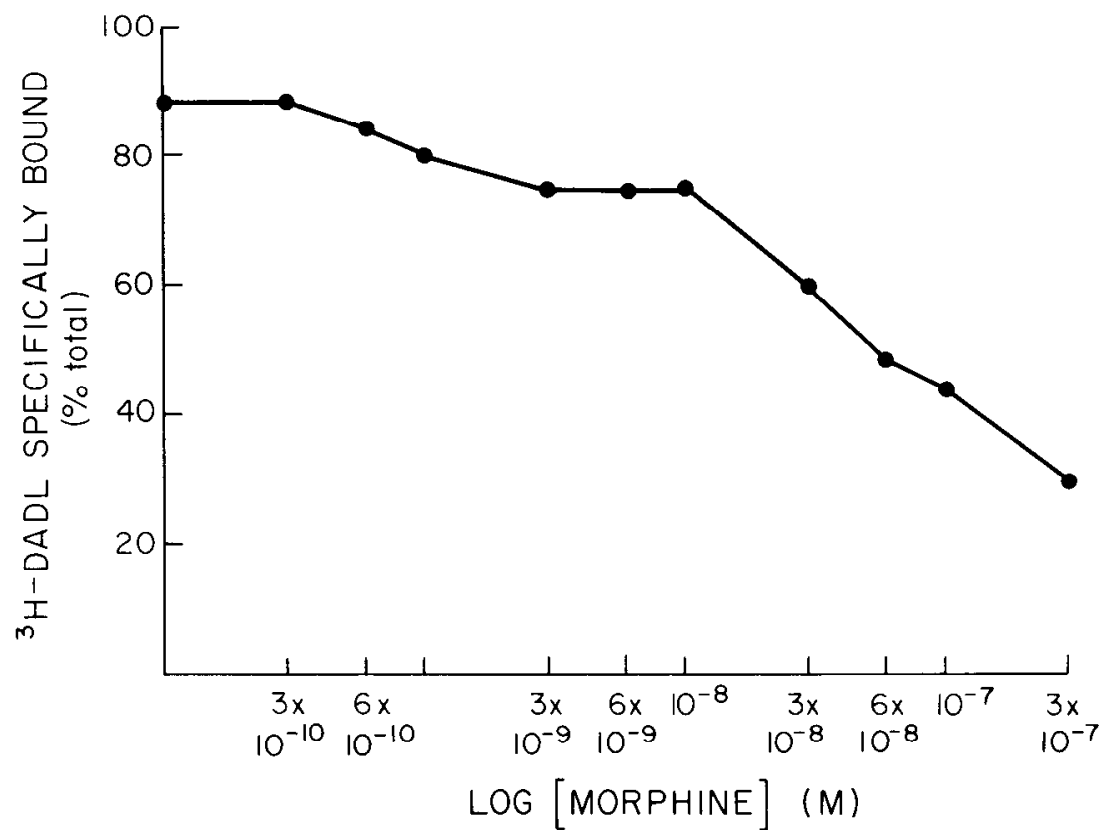

Figure 1. Displacement of specifically bound $\left[{ }^{3} \mathrm{H}\right] \mathrm{DADL}(4.5 \mathrm{~nm})$ by morphine in brain homogenates. Tritiated DADL binding was decreased to $75 \%$ of the control value ( $\left[{ }^{3} \mathrm{H}\right] \mathrm{DADL}$ alone) by 0.1 to $3 \mathrm{nM}$ morphine. A plateau, at $75 \%$ of control binding, occurred in the competition curve with 3 to $10 \mathrm{nM}$ morphine, and $\left[{ }^{3} \mathrm{H}\right] \mathrm{D} \Lambda \mathrm{DL}$ binding was again decreased by 30 to $300 \mathrm{nM}$ morphine.

(1971). Grain counts were made with a $\times 100$ oil immersion objective and calibrated grid under brightfield illumination. Sixty $10-\mu \mathrm{m}^{2}$ divisions were counted for each anatomical area on each tissue section. The number of specific grains was determined by subtracting grain counts for control sections $\left({ }^{3} \mathrm{H}\right.$-ligand $+1.0 \mu \mathrm{M}$ levallorphan) from the grain counts for sections labeled with $\left[{ }^{3} \mathrm{H}\right] \mathrm{DHM}$ or $\left[{ }^{3} \mathrm{H}\right] \mathrm{DADL}+2.5 \mathrm{nM}$ morphine. Quantification was performed according to a procedure described elsewhere (Unnerstall et al., 1982). Standard slides, with sections of brain paste containing known levels of tritiated ornithine, were processed as described above and were used to convert silver grain density to disintegrations per minute per milligram of tissue [ log disintegrations per minute per milligram of tissue $=m(\log$ silver grain density) $+b]$. The disintegrations per minute per milligram of tissue were converted to femtomoles per milligram of tissue using the specific activity of the ${ }^{3} \mathrm{H}$ ligands $(\mathrm{DHM}=90 \mathrm{Ci} / \mathrm{mmol}, \mathrm{DADL}=32 \mathrm{Ci} / \mathrm{mmol})$. Statistical analysis used the Student's $t$-test, two-tailed, analysis of variance, and Neuman-Keuls test. Photographs were taken with a Zeiss camera and Kodak Panatomic-X film.

Since all of the slides could not be processed for autoradiography in 1 day, a group of adjacent striatum sections was processed on each day to control for possible variations in conditions. Duplicate samples of each anatomical level from one mouse were processed on consecutive days.

\section{Results}

\section{Binchemistry experiments}

Saturation studies. In brain homogenates, $\left[{ }^{3} \mathrm{H}\right] \mathrm{DHM}$ bound with a $K_{D}=1.06 \mathrm{nM}$ and a $B_{\max }=6.36 \mathrm{fmol} / \mathrm{mg}$ of tissue. Tritiated DADL bound with a $K_{D}=5.09 \mathrm{nM}$ and a $B_{\max }=19.34 \mathrm{fmol} / \mathrm{mg}$ of tissue. These $K_{D} \mathrm{~s}$ represent averages of the affinity of DHM for $\mu_{1}$ and $\mu_{2}$ sites and of DADL for $\mu_{1}$ and $\delta$ sites (see "Discussion").

Competition studies. In brain homogenate and on-theslide experiments, the binding of $4.5 \mathrm{nM}\left[{ }^{3} \mathrm{H}\right] \mathrm{DADL}$ (Fig. 1) was decreased to $75 \%$ of the control value by 0.1 to 3 nM morphine. A plateau in the competition curve occurred with 3 to $10 \mathrm{nM}$ morphine, and further $\left[{ }^{3} \mathrm{H}\right] \mathrm{DADL}$ binding was displaced by 30 to $300 \mathrm{nM}$ morphine. At 300 nM morphine, the binding of $\left[{ }^{3} \mathrm{H}\right] \mathrm{DADL}$ was $30 \%$ of the control value.

\section{Autoradiography experiments}

The quantified autoradiography results are shown in Tables I to IV. The specific grain counts represent mean values from two to four mice. Grain counts were converted to disintegrations per minute per milligram of tissue using the standard curve (log disintegrations per minute per milligram of tissue versus $\log$ grains $/ 10 \mu \mathrm{m}^{2}$; $r=0.97, m=1.01, b=2.44)$. The specific activities of the ${ }^{3} \mathrm{H}$-ligands were then used to calculate femtomoles of ${ }^{3} \mathrm{H}$-ligand bound per milligram of tissue. ${ }^{4}$ It was not possible to determine accurately the total number of binding sites, because this would involve significant assumptions (see "Discussion").

Grain counts from sections through the rostral striatum, which were processed on different days, were not significantly different. For example, for $\delta$ sites in laminae II/III of frontal cortex the grain counts (mean \pm SEM)

\footnotetext{
${ }^{4}$ Disintegrations per minute per milligram of tissue $=10^{1.01}[\log$ (silver grain density)] +2.44 . Femtomoles of ${ }^{3} \mathrm{H}$-ligand bound per milligram of tissue $=$ disintegrations per minute per milligram of tissue/ [specific activity $\left.\left(2.22 \times 10^{3} \mathrm{dpm} / \mathrm{nCi}\right)\right]$.
} 
for these sections were: day $1: 12 \pm 0.08$; day $2: 15 \pm$ 0.09 ; day $3: 15 \pm 0.08$; day $4: 12 \pm 0.09$.

\section{Telencephalon (Fig. 2 and Tables I and II)}

$\mu$ and $\delta$ sites were noted throughout the neocortex, although their distributions differed (Fig. 3 ). $\delta$ sites were diffusely distributed throughout the laminae, whereas $\mu$ sites were concentrated in laminae I, IV, and VI. $\mu$ and $\delta$ sites were also observed in the pyriform cortex and olfactory tubercle. Other areas with $\mu$ and $\delta$ sites were the interstitial nucleus of the stria terminalis and the nucleus of the tract of the diagonal band of Broca.

In the extrapyramidal motor system, $\mu$ and $\delta$ sites were

TABLE I

$\mu$ and $\delta$ binding sites: Telencephalon

\begin{tabular}{|c|c|c|c|c|c|}
\hline \multirow{3}{*}{$\begin{array}{l}\text { Frontal cortex } \\
I^{d}\end{array}$} & \multicolumn{2}{|c|}{$\begin{array}{c}\mu^{n} \\
\text { Ligand Bound } \\
\pm \mathrm{SEM}^{b}\end{array}$} & \multicolumn{2}{|c|}{$\begin{array}{c}\delta^{r} \\
\text { Ligand Bound } \\
\pm \mathrm{SEM}^{b}\end{array}$} & \multirow[t]{2}{*}{$\mu / \delta$} \\
\hline & \multicolumn{2}{|c|}{$\begin{array}{l}\text { fmol/mg } \\
\text { of tissue }\end{array}$} & \multicolumn{2}{|c|}{$\begin{array}{l}\text { fmol/mg } \\
\text { of tissue }\end{array}$} & \\
\hline & 22.7 & 0.85 & 39.7 & 1.15 & 0.57 \\
\hline $\mathrm{II} / \mathrm{III}^{d}$ & 8.4 & 0.53 & 39.7 & 1.30 & 0.21 \\
\hline $\mathrm{IV}^{d}$ & 12.7 & 0.66 & 43.7 & 1.38 & 0.29 \\
\hline $\mathrm{V}^{d}$ & 11.3 & 0.84 & 63.8 & 1.69 & 0.18 \\
\hline $\mathrm{VI}^{d}$ & 11.3 & 0.62 & 35.7 & 1.15 & 0.32 \\
\hline \multicolumn{6}{|l|}{ Parietal cortex } \\
\hline $\mathrm{I}^{d}$ & 17.0 & 0.68 & 31.7 & 1.15 & 0.54 \\
\hline $\mathrm{II} / \mathrm{III}^{d}$ & 9.8 & 0.50 & 51.7 & 1.38 & 0.19 \\
\hline $\mathrm{IV}^{d}$ & 18.4 & 0.71 & 51.7 & 1.58 & 0.36 \\
\hline $\mathrm{V}^{d}$ & 15.5 & 0.66 & 63.8 & 2.16 & 0.24 \\
\hline $\mathrm{VI}^{d}$ & 24.1 & 0.91 & 47.7 & 1.23 & 0.50 \\
\hline \multicolumn{6}{|l|}{ Occipital cortex } \\
\hline $\mathrm{I}^{d}$ & 5.6 & 0.42 & 19.7 & 0.99 & 0.28 \\
\hline $\mathrm{II} / \mathrm{III}^{d}$ & 7.0 & 0.48 & 43.7 & 1.69 & 0.16 \\
\hline $\mathrm{IV}^{d}$ & 12.7 & 0.46 & 19.7 & 0.96 & 0.64 \\
\hline $\mathrm{V}^{d}$ & 12.7 & 0.56 & 27.7 & 1.26 & 0.46 \\
\hline $\mathrm{VI}^{d}$ & 8.4 & 0.38 & 27.7 & 1.77 & 0.30 \\
\hline \multicolumn{6}{|l|}{ Temporal cortex } \\
\hline $\mathrm{I}^{d}$ & 19.8 & 0.59 & 27.7 & 1.38 & 0.71 \\
\hline $\mathrm{II} / \mathrm{III}^{d}$ & 9.8 & 0.52 & 59.8 & 1.85 & 0.16 \\
\hline $\mathrm{IV}^{d}$ & 22.7 & 0.68 & 31.7 & 1.23 & 0.72 \\
\hline $\mathrm{V}^{d}$ & 19.8 & 0.46 & 59.8 & 1.92 & 0.33 \\
\hline $\mathrm{VI}^{d}$ & 19.8 & 0.98 & 23.7 & 1.07 & 0.84 \\
\hline \multicolumn{6}{|l|}{ Pyriform cortex } \\
\hline Pyramidal layer ${ }^{d}$ & 19.8 & 0.68 & 27.7 & 0.57 & 0.71 \\
\hline Polymorph layer $^{d}$ & 18.4 & 0.64 & 31.7 & 1.23 & 0.58 \\
\hline Plexiform layer ${ }^{d}$ & 18.4 & 0.67 & 43.7 & 1.58 & 0.42 \\
\hline \multicolumn{6}{|l|}{ Olfactory tubercle } \\
\hline Pyriform layer $^{d}$ & 15.5 & 0.70 & 47.7 & 1.69 & 0.3 \\
\hline Polymorph layer ${ }^{d}$ & 18.4 & 0.86 & 39.7 & 1.34 & 0.46 \\
\hline Plexiform layer $^{d}$ & 18.4 & 0.64 & 39.7 & 1.50 & 0.46 \\
\hline $\begin{array}{l}\text { Nucleus of the tract of the diagonal } \\
\text { band of Broca }\end{array}$ & 24.1 & 0.81 & 27.7 & 1.15 & 0.87 \\
\hline $\begin{array}{l}\text { Interstitial nucleus of the stria } \\
\text { terminalis }\end{array}$ & 78.5 & 2.01 & 71.8 & 1.85 & 1.09 \\
\hline
\end{tabular}

\footnotetext{
${ }^{a} \mu$ sites were visualized using $1.7 \mathrm{nM}\left[{ }^{3} \mathrm{H}\right] \mathrm{DHM}$.

${ }^{b}$ Grain counts (mean number of silver grains per $10 \mu \mathrm{m}^{2}$, range $=5$ to 55 grains $/ 10 \mu \mathrm{m}^{2}$ ) were converted to disintegrations per minute per milligram of tissue using the standard curve. The disintegrations per minute per milligram of tissue were converted to femtomoles per milligram of tissue using the specific activities of the tritiated ligands $(\mathrm{DHM}=90 \mathrm{Ci} / \mathrm{mmol}, \mathrm{DADL}=32 \mathrm{Ci} / \mathrm{mmol})$. Grain counts were pooled from at least two subjects.

${ }^{c} \delta$ sites were visualized using $4.5 \mathrm{nM}\left[{ }^{3} \mathrm{H}\right] \mathrm{DADL}+2.5 \mathrm{nM}$ morphine.

${ }^{d}$ Statistically significant ( $p<0.001$, the Student's $t$ test, two-tailed) difference between the amount of ligand bound by $\mu$ and $\delta$ sites.
}

TABLE II

$\mu$ and $\delta$ binding sites: telencephalon

$\begin{array}{ccc}\mu^{a} \\ \text { Area } & \begin{array}{c}\delta^{c} \\ \pm \mathrm{SEM}^{b}\end{array} & \begin{array}{c}\text { Ligand Bound } \\ \pm \mathrm{SEM}^{b}\end{array} \\ & \mu / \delta\end{array}$

fmol/mg of tissue fmol/mg of tissue

\begin{tabular}{|c|c|c|c|c|c|}
\hline \multicolumn{6}{|l|}{ Extrapyramidal system } \\
\hline Striatum: patches & 92.0 & 1.91 & & & \\
\hline \multicolumn{6}{|l|}{ Striatum: diffuse } \\
\hline Rostral $^{d}$ & 42.8 & 1.27 & 63.8 & 1.77 & 0.67 \\
\hline Caudal $^{d}$ & 15.5 & 0.57 & 47.7 & 1.61 & 0.32 \\
\hline Ventral pallidum $^{d}$ & 92.0 & 2.19 & 55.7 & 2.12 & 1.65 \\
\hline Globus pallidus & 15.5 & 0.55 & 15.7 & 0.69 & 0.99 \\
\hline Claustrum $^{d}$ & 42.8 & 1.02 & 35.7 & 1.26 & 1.20 \\
\hline \multicolumn{6}{|l|}{ Limbic system } \\
\hline \multicolumn{6}{|l|}{ Nucleus accumbens } \\
\hline Rostral & 28.4 & 1.04 & 23.7 & 1.15 & 1.20 \\
\hline Caudal $^{d}$ & 153.1 & 5.51 & 55.7 & 2.08 & 2.75 \\
\hline \multicolumn{6}{|l|}{ Hippocampus ${ }^{e}$} \\
\hline $\mathrm{MCA}^{d}$ & 11.3 & 0.37 & 19.7 & 0.72 & 0.57 \\
\hline $\mathrm{MCA} 2^{d}$ & 8.4 & 0.34 & 27.7 & 0.84 & 0.30 \\
\hline $\mathrm{MCA}^{d}$ & 22.7 & 0.63 & 31.7 & 0.96 & 0.72 \\
\hline $\mathrm{PCA}^{d}$ & 9.8 & 0.37 & 31.7 & 0.99 & 0.31 \\
\hline $\mathrm{PCA}^{d}$ & 12.7 & 0.38 & 31.7 & 0.76 & 0.40 \\
\hline $\mathrm{PCA}^{d}$ & 9.8 & 0.34 & 27.7 & 0.96 & 0.35 \\
\hline \multicolumn{6}{|l|}{ Amygdala } \\
\hline Central nucleus & 47.1 & 0.77 & 51.7 & 2.04 & 0.91 \\
\hline Medial nucleus & 50.0 & 1.09 & 43.7 & 1.61 & 1.14 \\
\hline Basal nucleus ${ }^{d}$ & 58.6 & 0.98 & 83.9 & 2.12 & 0.70 \\
\hline Lateral nucleus ${ }^{d}$ & 12.7 & 0.59 & 75.9 & 1.85 & 0.17 \\
\hline Cortical nucleus ${ }^{d}$ & 22.7 & 0.70 & 75.9 & 2.94 & 0.30 \\
\hline Transitional corticoamygdaloid & 35.6 & 0.84 & 39.7 & 2.00 & 0.90 \\
\hline
\end{tabular}
area

${ }^{a} \mu$ sites were visualized using $1.7 \mathrm{nM}\left[{ }^{3} \mathrm{H}\right] \mathrm{DHM}$.

${ }^{b}$ Grain counts (mean number of silver grains per $10 \mu \mathrm{m}^{2}$, range $=4$ to 106 grains $/ 10 \mu \mathrm{m}^{2}$ ) were converted to disintegrations per minute per milligram of tissue using the standard curve. The disintegrations per minute per milligram of tissue were converted to femtomoles per milligram of tissue using the specific activities of the tritiated ligands $(\mathrm{DHM}=90 \mathrm{Ci} / \mathrm{mmol}, \mathrm{DADL}=32 \mathrm{Ci} / \mathrm{mmol})$. Grain counts were pooled from at least two subjects.

${ }^{c} \delta$ sites were visualized using $4.5 \mathrm{nM}\left[{ }^{3} \mathrm{H} \mid \mathrm{DADL}+2.5 \mathrm{nM}\right.$ morphine.

${ }^{d}$ Statistically significant ( $p<0.001$, the Student's $t$ test, two-tailed) difference between the amount of ligand bound by $\mu$ and $\delta$ sites.

${ }^{e} \mathrm{M}$, stratum laconosum-moleculare; $\mathrm{P}$, stratum pyramidale.

found in the striatum, ventral pallidum, globus pallidus, and claustrum. In the striatum both sites were more numerous in the rostral portion $\left(t_{\mu}(238)=22.20, t_{\delta}(238)\right.$ $=6.58, p<0.001)$. In addition, $\delta$ sites were diffusely distributed throughout the striatum, whereas $\mu$ sites occurred both in patches and diffusely between patches. These patches were present throughout the striatum at rostral levels, predominantly in the ventral part at intermediate levels, and were absent at caudal levels.

$\mu$ and $\delta$ sites also occurred in the hippocampus, amygdala, and nucleus accumbens. In the latter, they were more dense at caudal than at rostral levels $\left(t_{\mu}(118)=\right.$ $\left.22.24, t_{\delta}(118)=14.50, p<0.001\right)$. In the hippocampus, $\mu$ sites were more numerous in area CA 3 than in areas CA1 or CA2 of the stratum laconosum-moleculare, whereas in the stratum pyramidale (Fig. 4) $\mu$ sites were evenly distributed in areas CA1 through CA3. $\delta$ sites were slightly higher in density in areas CA2 and CA3 than in area $\mathrm{CA} 1$ of the stratum laconosum-moleculare and were evenly distributed in areas CA1 through CA 3 of the 
TABLE III

$\mu$ and $\delta$ binding sites: Diencephalon and mesencephalon

\begin{tabular}{|c|c|c|c|c|c|}
\hline \multirow{3}{*}{$\begin{array}{l}\text { Area } \\
\text { Diencephalon }\end{array}$} & \multicolumn{2}{|c|}{$\begin{array}{c}\mu^{\alpha} \\
\text { Ligand Bound } \\
\pm \mathrm{SEM}^{b}\end{array}$} & \multicolumn{2}{|c|}{$\begin{array}{c}\delta^{c} \\
\text { Ligand Bound } \\
\pm \mathrm{SEM}^{b}\end{array}$} & \multirow[t]{2}{*}{$\mu / \delta$} \\
\hline & \multicolumn{4}{|c|}{$\mathrm{fmol} / \mathrm{mg}$ of tissue $\mathrm{fmol} / \mathrm{mg}$ of tissue } & \\
\hline & & & & & \\
\hline Preoptic area & 55.8 & 2.05 & 58.8 & 2.24 & 0.95 \\
\hline Hypothalamus & 34.2 & 0.82 & 31.7 & 1.45 & 1.08 \\
\hline Medial mammillary nucleus ${ }^{d}$ & 42.8 & 1.02 & 31.7 & 1.54 & 1.35 \\
\hline Lateral mammillary nucleus ${ }^{d}$ & 28.4 & 1.25 & 19.7 & 1.58 & 1.44 \\
\hline Medial thalamus ${ }^{d}$ & 96.3 & 1.25 & 63.8 & 1.58 & 1.51 \\
\hline Subthalamic nuc & 34.2 & 1.10 & 23.7 & 1.11 & 1.44 \\
\hline Medial habenule & 119.6 & 2.36 & 47.5 & 3.13 & 2.52 \\
\hline \multicolumn{6}{|l|}{ Mesencephalon } \\
\hline Superior colliculus ${ }^{d}$ & 26.8 & 0.57 & 15.7 & 0.72 & 1.71 \\
\hline \multicolumn{6}{|l|}{ Periaqueductal gray matter } \\
\hline Dorsal & 25.5 & 0.44 & 23.7 & 0.88 & 1.08 \\
\hline Ventral $^{d}$ & 32.7 & 0.66 & 23.7 & 0.72 & 1.38 \\
\hline Raphe nuclei & 21.2 & 0.67 & 19.7 & 0.80 & 1.08 \\
\hline \multicolumn{6}{|l|}{ Substantia nigra } \\
\hline Pars compacta & 14.1 & 0.39 & 15.7 & 0.61 & 0.90 \\
\hline Pars reticulata $^{d}$ & 9.8 & 0.34 & 15.7 & 1.07 & 0.62 \\
\hline Interpeduncular nucleus ${ }^{d}$ & 70.2 & 1.68 & 31.7 & 1.15 & 2.21 \\
\hline Reticular formation & 12.7 & 0.55 & 15.7 & 0.76 & 0.81 \\
\hline
\end{tabular}

${ }^{a}{ }_{\mu}$ sites were visualized using $1.7 \mathrm{nM}\left[{ }^{3} \mathrm{H}\right] \mathrm{DHM}$.

${ }^{b}$ Grain counts (mean number of silver grains $/ 10 \mu \mathrm{m}^{2}$, range $=4$ to 83 grains $/ 10 \mu \mathrm{m}^{2}$ ) were converted to disintegrations per minute per milligram of tissue using the standard curve. The disintegrations per minute per milligram of tissue were converted to femtomoles per milligram of tissue using the specific activities of the tritiated ligands $(\mathrm{DHM}=90 \mathrm{Ci} / \mathrm{mmol}, \mathrm{DADL}=32 \mathrm{Ci} / \mathrm{mmol})$. Grain counts were pooled from at least two subjects.

${ }^{c} \delta$ sites were visualized using $4.5 \mathrm{nM}\left[{ }^{3} \mathrm{H}\right] \mathrm{DADL}+2.5 \mathrm{nM}$ morphine.

${ }^{d}$ Statistically significant ( $p<0.001$, the Student's $t$ test, two-tailed) difference between the amount of ligand bound by $\mu$ and $\delta$ sites.

TARLE IV

$\mu$ and $\delta$ binding sites: Myelencephalon and spinal cord

\begin{tabular}{|c|c|c|c|c|c|}
\hline \multirow[t]{2}{*}{ Area } & \multicolumn{2}{|c|}{$\begin{array}{l}\mu^{\alpha} \\
\text { Ligand Bound } \\
\pm \mathrm{SEM}^{b}\end{array}$} & \multicolumn{2}{|c|}{$\begin{array}{c}\delta^{c} \\
\text { Ligand Bound } \\
\pm \mathrm{SEM}^{b}\end{array}$} & $\mu / \delta$ \\
\hline & \multicolumn{2}{|c|}{$\mathrm{fmol} / \mathrm{mg}$ of tissue } & \multicolumn{3}{|c|}{ fmol/mg of tissue } \\
\hline \multicolumn{6}{|l|}{ Myelencephalon } \\
\hline $\begin{array}{l}\text { Nucleus of the tract of the } \\
\text { trigeminal nerve: sub- } \\
\text { stantia gelatinosa-pars } \\
\text { caudalis }\end{array}$ & 55.8 & 1.43 & 55.7 & 1.96 & 1.00 \\
\hline $\begin{array}{l}\text { Dorsal nucleus of the vagus } \\
\text { nerve }\end{array}$ & 31.3 & 0.78 & 31.7 & 0.99 & 0.99 \\
\hline Nucleus of the solitary tract & 15.5 & 0.48 & 15.7 & 0.72 & 0.99 \\
\hline Reticular formation ${ }^{d}$ & 15.5 & 0.67 & 11.8 & 0.72 & 1.32 \\
\hline \multicolumn{6}{|l|}{ Spinal cord } \\
\hline Lamina $\mathrm{I} / \mathrm{II}^{d}$ & 86.2 & 2.13 & 59.8 & 1.19 & 1.44 \\
\hline Lamina V & 18.4 & 0.62 & 19.7 & 0.80 & 0.93 \\
\hline Lamina $\mathrm{X}$ & 12.7 & 0.60 & 15.7 & 1.03 & 0.81 \\
\hline
\end{tabular}

${ }^{a} \mu$ sites were visualized using $1.7 \mathrm{nM}\left[{ }^{3} \mathrm{H}\right] \mathrm{DHM}$.

${ }^{b}$ Grain counts (mean number of silver grains $/ 10 \mu \mathrm{m}^{2}$, range $=4$ to 83 grains $/ 10 \mu \mathrm{m}^{2}$ ) were converted to disintegrations per minute per milligram of tissue using the standard curve. The disintegrations per minute per milligram of tissue were converted to femtomoles per milligram of tissue using the specific activities of the tritiated ligands $(\mathrm{DHM}=90 \mathrm{Ci} / \mathrm{mmol}, \mathrm{DADL}=32 \mathrm{Ci} / \mathrm{mmol})$. Grain counts were pooled from at least two subjects.

${ }^{c} \delta$ sites were visualized using $4.5 \mathrm{nM}\left[{ }^{3} \mathrm{H}\right] \mathrm{DADL}+2.5 \mathrm{nM}$ morphine.

${ }^{d}$ Statistically significant ( $p<0.001$, the Student's $t$ test, two-tailed) difference between the amount of ligand bound by $\mu$ and $\delta$ sites. stratum pyramidale. In the amygdala, $\mu$ sites were most numerous in the central, medial, and basal nuclei, whereas $\delta$ sites were numerous in all of the amygdaloid nuclei.

\section{Diencephalon (Fig. 5 and Table III)}

$\mu$ and $\delta$ sites were found throughout the preoptic area, hypothalamus, in the mammillary body, midline and medial thalamic nuclei, medial habenular nucleus, and subthalamic nucleus. A particularly high level of $\mu$ sites was observed in the midline and medial thalamic nuclei and in the medial habenular nucleus.

\section{Mesencephalon (Table III)}

$\mu$ and $\delta$ sites were seen in the superior colliculus, periaqueductal gray matter, raphe nuclei, substantia nigra, interpeduncular nucleus, and reticular formation. In the periaqueductal gray matter, a significantly $(t(238)=$ $9.08, p<0.001$ ) higher number of $\mu$ sites was noted ventrally than dorsally. In the substantia nigra, a significantly $(t(418)=8.30, p<0.001)$ higher number of $\mu$ sites was observed in the pars compacta than in the pars reticulata. A particularly high number of $\mu$ sites was seen in the interpeduncular nucleus.

\section{Myelencephalon and spinal cord (Table IV)}

In the myelencephalon, $\mu$ and $\delta$ sites were observed in the substantia gelatinosa of the nucleus of the spinal tract of the trigeminal nerve-pars caudalis, dorsal nucleus of the vagus nerve, nucleus of the solitary tract, and reticular formation. In the cervical spinal cord they were found in laminae I, II, V, and X. A particularly high level of $\mu$ sites was found in laminae I and II.

\section{Discussion}

Our absernations on the distribution of aproid binding sites in the mouse CNS correlate well with earlier studies done in the rat (Pert et al., 1975, 1976; Atweh and Kuhar, $1977 \mathrm{a}, \mathrm{b}, \mathrm{c}$; Pearson et al., 1980) using in vivo autoradiography techniques. However, these studies did not discriminate different binding site populations.

Work using in vitro autoradiography techniques has differentiated the distribution of $\mu$ and $\delta$ sites in the rat CNS (Goodman et al., 1980; Duka et al., 1981a, b). However, this work has not provided a quantified analysis of $\mu$ and $\delta$ site distributions as has been presented in this paper. Our data have been presented as femtomoles of ligand bound per milligram of tissue dry weight. To estimate the concentration of binding sites, however, the percentage of occupancy would have to be determined, and this would depend on several assumptions. These include total reversibility of ligand binding and noncooperativity of binding, as well as a major assumption of binding of ${ }^{8} \mathrm{H}$-ligand to a single receptor population. The latter assumption is almost certainly not valid with the opioid binding described here. Tritiated DHM apparently binds to at least two subpopulations of $\mu$ sites $\left(\mu_{1}\right.$ and $\mu_{2}$ ) with different $K_{I}$ s (Wolozin and Pasternak, 1981 ), so that the percentage of occupancy of sites in any one area will depend on the relative proportion of $\mu_{1}$ to $\mu_{2}$ sites. Tritiated DADL appears to bind with highest affinity to $\mu_{1}$ sites, and the remainder of its binding seems to be to $\delta$ sites. Tritiated DADL binding to $\mu_{1}$ sites 

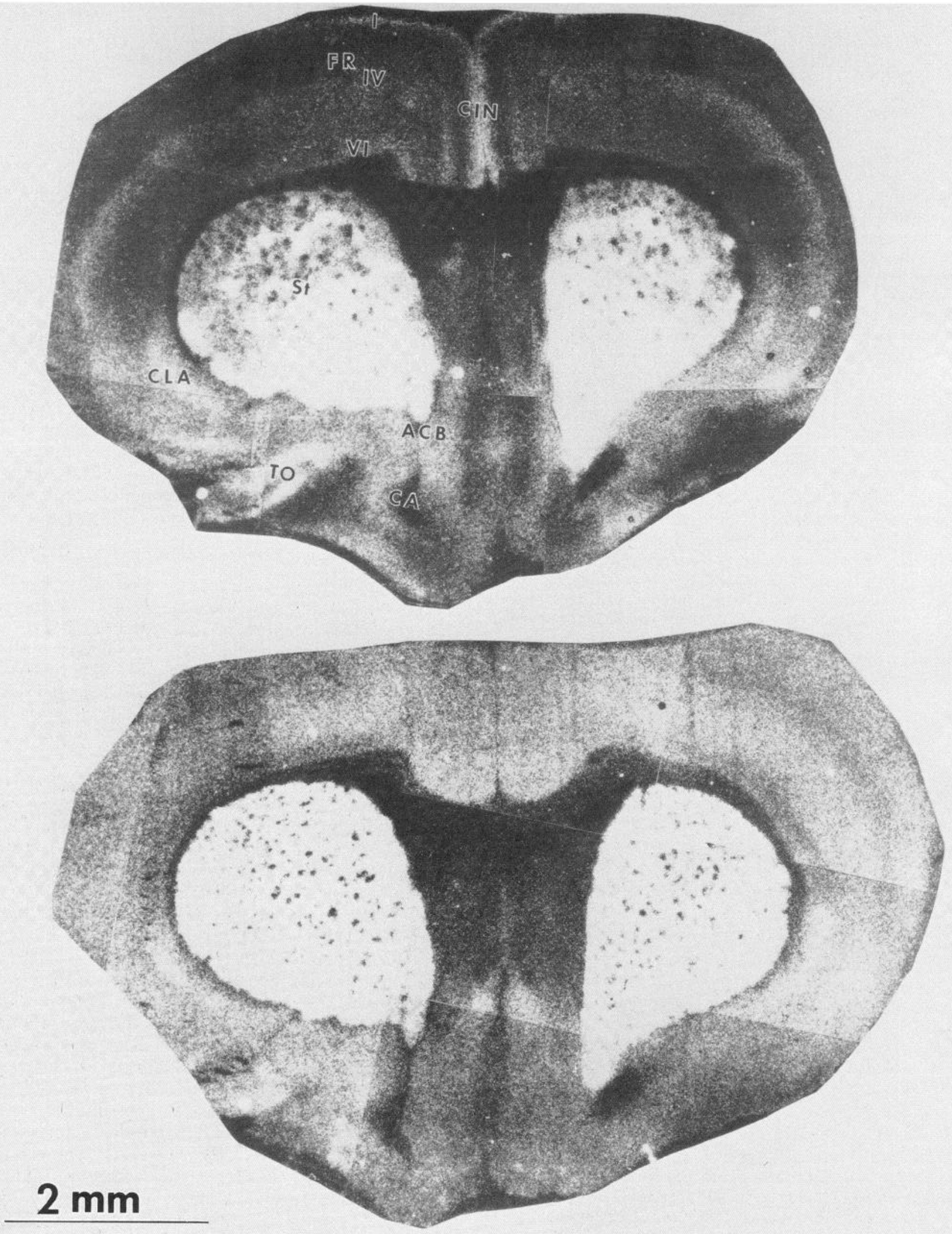

Figure 2. Darkfield autoradiogram of $\mu$ (top) and $\delta$ (bottom) binding sites in the telencephalon. $\mu$ sites were visualized using $1.7 \mathrm{nM}\left[{ }^{3} \mathrm{H}\right] \mathrm{DHM}$, and $\delta$ sites were visualized using $4.5 \mathrm{nM}\left[{ }^{3} \mathrm{H}\right] \mathrm{DADL}+2.5 \mathrm{nM}$ morphine. Note that $\mu$ sites occur in patches in the striatum $(S t)$, whereas $\delta$ sites are diffusely distributed throughout this area. $A C B$, nucleus accumbens; $C A$, anterior commissure; $C I N$, cingulate cortex; $C L A$, claustrum; $F R$, frontal cortex; $T O$, olfactory tubercle; $I$, IV, and $V I$, laminae of the neocortex. 

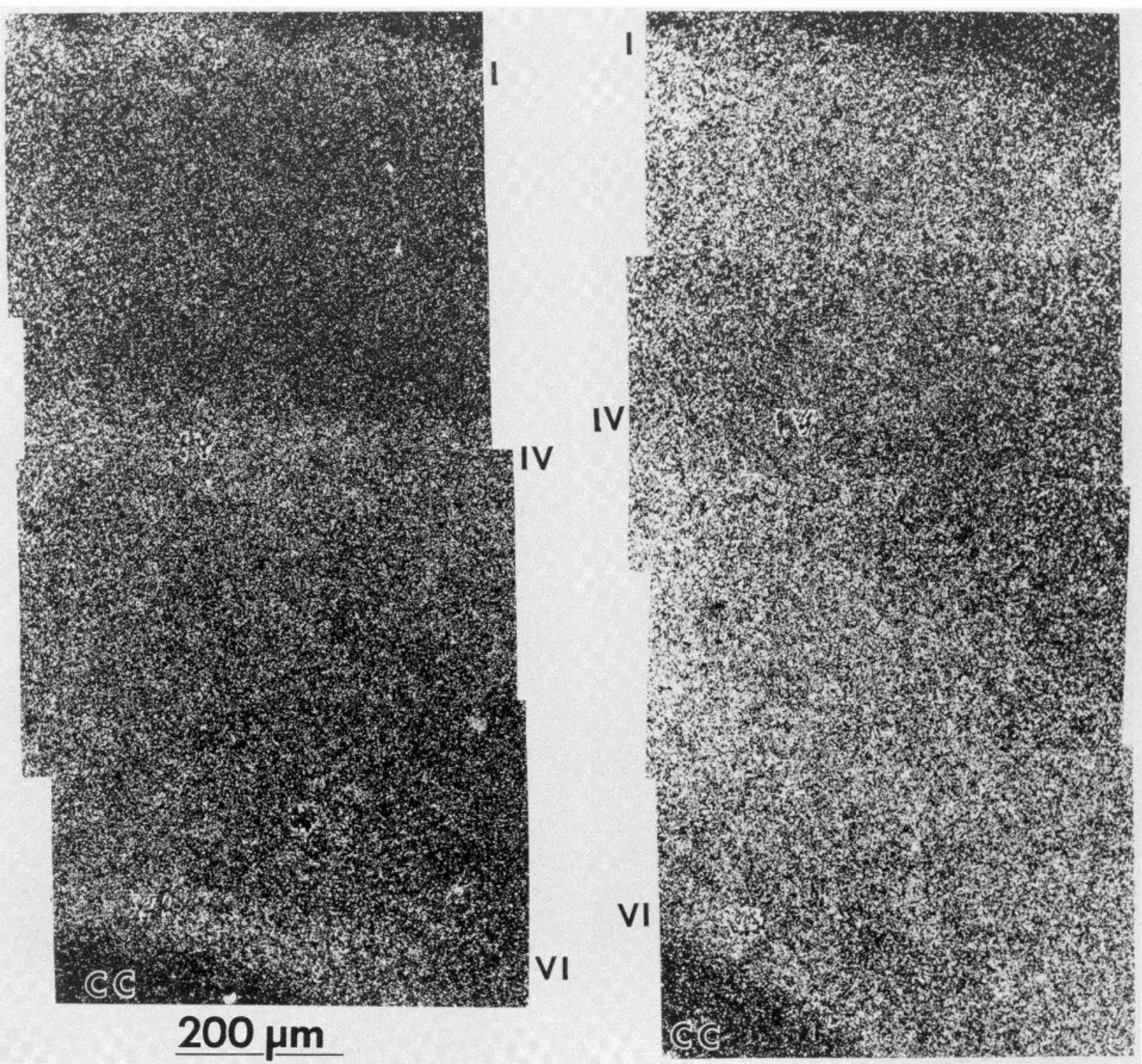

Figure 3. Darkfield autoradiogram of $\mu$ (left) and $\delta$ (right) binding sites in parietal cortex. $\mu$ sites were visualized using $1.7 \mathrm{nM}$ $\left[{ }^{3} \mathrm{H}\right] \mathrm{DHM}$, and $\delta$ sites were visualized using $4.5 \mathrm{nM}\left[{ }^{3} \mathrm{H}\right] \mathrm{DADL}+2.5 \mathrm{nM}$ morphine. Note that $\mu$ sites are concentrated in laminae $I, I V$, and $V I$, whereas $\delta$ sites are more diffusely distributed throughout the laminae. $C C$, corpus callosum.

was essentially eliminated by the addition of morphine (2.5 $\mathrm{nM})$, but the $K_{D}$ value we obtained represents saturation of both $\mu_{1}$ and $\delta$ sites. For $\left[{ }^{3} \mathrm{H}\right] \mathrm{DHM}$ binding the $K_{D}$ value we obtained represents binding to both $\mu_{1}$ and $\mu_{2}$ sites. Due to the relatively small number of points we used for each Scatchard plot, we obtained single $K_{D} \mathrm{~s}$ for the binding of $\left[{ }^{3} \mathrm{H}\right] \mathrm{DHM}$ and for the binding of $\left[{ }^{3} \mathrm{H}\right]$ DADL. In the autoradiography experiments $\left[{ }^{3} \mathrm{H}\right] \mathrm{DHM}$ was used to visualize both $\mu_{1}$ and $\mu_{2}$ sites, and, using the data obtained from the competition experiments, we were able to select conditions that allowed us to visualize $\delta$ sites selectively. Considering these factors, $\left[{ }^{3} \mathrm{H}\right] \mathrm{DHM}$ probably had an occupancy of approximately $100 \%$ for $\mu_{1}$ sites and approximately $62 \%$ for $\mu_{2}$ sites (percentage of occupancy $=[L] /[L]+K_{D}$ ), and $\left[{ }^{3}\right.$ H]DADL (assuming an approximate $K_{D}$ ) for $\delta$ sites of $5.09 \mathrm{nM}$ ) had an occupancy of approximately $47 \%$ for $\delta$ sites. These approximations could be used to calculate a receptor density, but we have chosen to present our data in the raw form of the density of ligand bound in order to avoid the assumptions discussed above.

Distributions in the mouse CNS correlate with those in the rat CNS in several areas (Goodman et al., 1980; Duka et al., 1981a, b). We found that $\delta$ sites were diffusely distributed throughout the neocortex and striatum, whereas $\mu$ sites were concentrated in laminae I, IV, and VI of the neocortex and in patches in the rostral striatum. As in the rat, a high ratio of $\mu / \delta$ binding occurred in the medial and midline thalamic nuclei, ventral periaqueductal gray matter, and interpeduncular nucleus; a low ratio of $\mu / \delta$ binding was noted in the olfactory tubercle; and an equal ratio of $\mu / \delta$ binding was present in the nucleus of the tract of the diagonal band of Broca, rostral nucleus accumbens, preoptic area, hypothalamus, substantia gelatinosa of the nucleus of the spinal tract of the trigeminal nerve-pars caudalis, and nucleus of the solitary tract.

We analyzed several areas for which the distributions 
of $\mu$ and $\delta$ sites have not been previously described. Relatively high ratios of $\mu / \delta$ binding were noted in the ventral pallidum, claustrum, medial and lateral mammillary nuclei, superior colliculus, medullary reticular formation, and laminae I and II of the spinal cord. Low ratios of $\mu / \delta$ binding were seen in the pyriform cortex, cortical nucleus of the amygdala, and substantia nigrapars reticulata. Equal ratios of $\mu / \delta$ binding were found in the globus pallidus, central and medial nuclei of the amygdala, substantia nigra-pars compacta, mesencephalic reticular formation, dorsal nucleus of the vagus nerve, and laminae $\mathrm{V}$ and $\mathrm{X}$ of the spinal cord. We also observed opioid binding in the subthalamic nucleus (high $\mu / \delta$ ratio) and in the transitional corticoamygdaloid area (equal $\mu / \delta$ ratio), neither of which has been reported to contain opioid binding sites, although both have enkephalin-immunoreactive fibers and terminals in the mouse (A. S. Moskowitz, J. C. Liebeskind, and L. L. Butcher, unpublished data).

In several areas we noted rostrocaudal or dorsoventral differences in the distribution of opioid binding sites. In the nucleus accumbens, there were more $\mu$ and $\delta$ sites caudally than rostrally. In the striatum we found more $\mu$ and $\delta$ sites rostrally than caudally. We also noted that $\mu$ site patches were found throughout the striatum at ros-

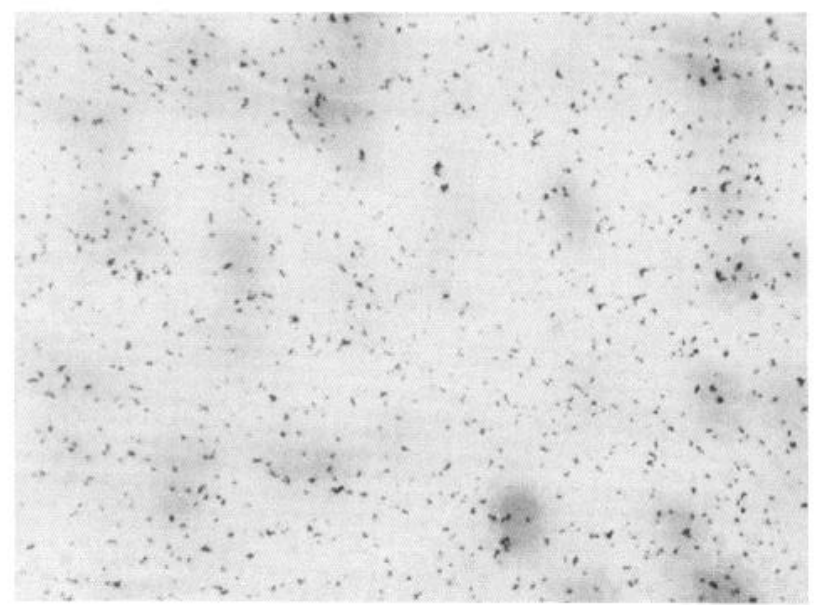

tral levels, predominantly in the ventral part at intermediate levels, and were absent at caudal levels. Using in vivo methods, Pearson et al. (1980) also found more binding site patches in the rostral than in the caudal striatum. With the in vitro technique, however, Herkenham and Pert (1980) reported no rostrocaudal patch frequency differences in the rat striatum, although they did note a decrease in the number of interpatch sites from rostral to caudal levels. The differences between our findings and those of Herkenham and Pert may reflect species differences. The rostrocaudal variations we noted in the level of sites in the nucleus accumbens and striatum are paralleled by rostrocaudal differences in the level of enkephalin-immunoreactive fibers and terminals in these areas in the mouse (A. S. Moskowitz, J. C. Liebeskind, and L. L. Butcher, unpublished data). Thus, more immunoreactive fibers and terminals are found in the caudal than in the rostral nucleus accumbens. At rostral levels of the striatum moderate numbers of immunoreactive fibers and terminals are seen throughout, at intermediate levels moderate numbers are noted ventrally with a low number dorsally, and at caudal levels low numbers are seen throughout.

In the periaqueductal gray matter, $\mu$ sites were more frequent ventrally than dorsally. Again, this parallels the

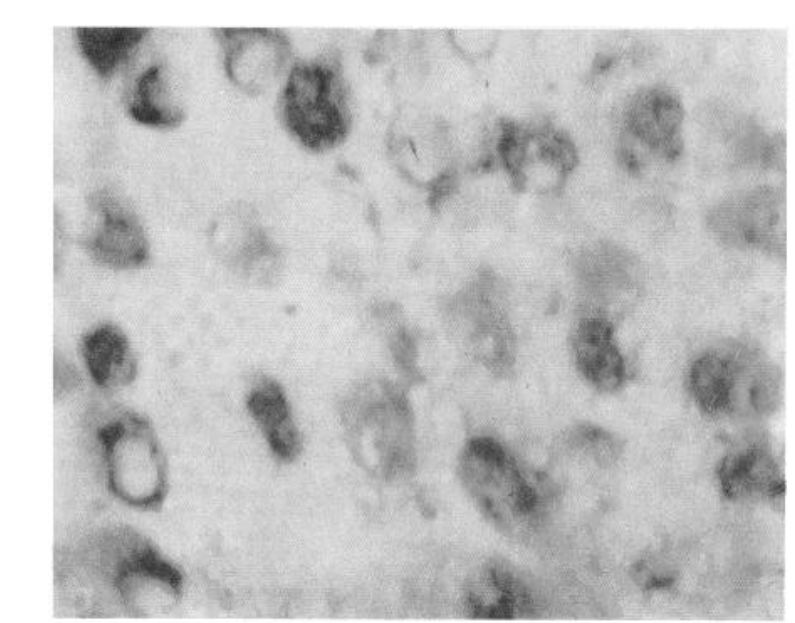

A

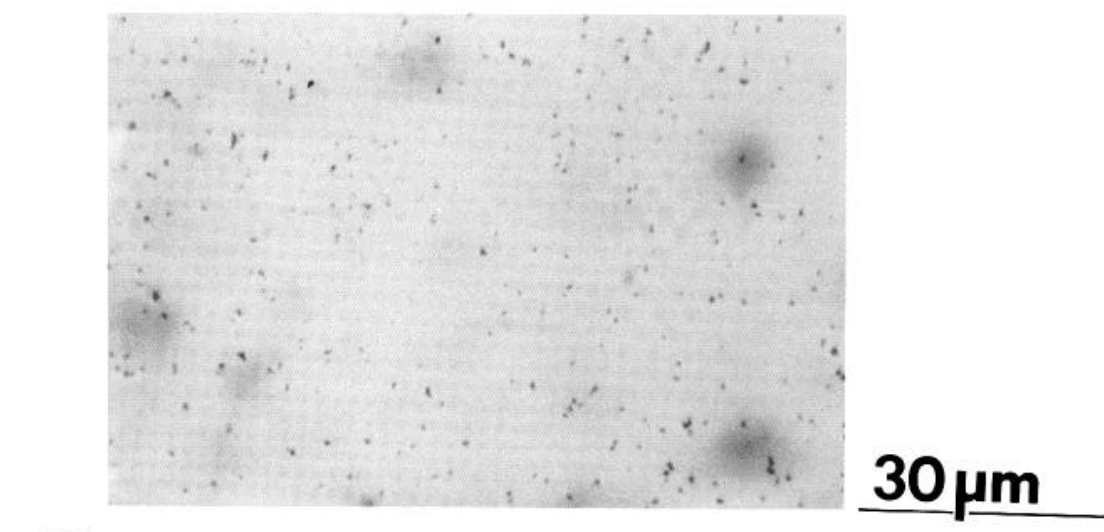

B

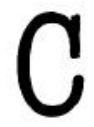

Figure 4. Brightfield autoradiogram of $\mu$ binding sites in the stratum pyramidale of hippocampal area CA2. $\mu$ sites were visualized using $1.7 \mathrm{nM}\left[{ }^{3} \mathrm{H}\right] \mathrm{DHM}$. Note that the silver grains $(A)$ lie within the neuropil as well as over pyramidal cells $(B)$. Also note the low level of grains in the section incubated with $1.7 \mathrm{nM}\left[{ }^{3} \mathrm{H}\right] \mathrm{DHM}+1.0 \mu \mathrm{M}$ levallorphan $(C)$. 

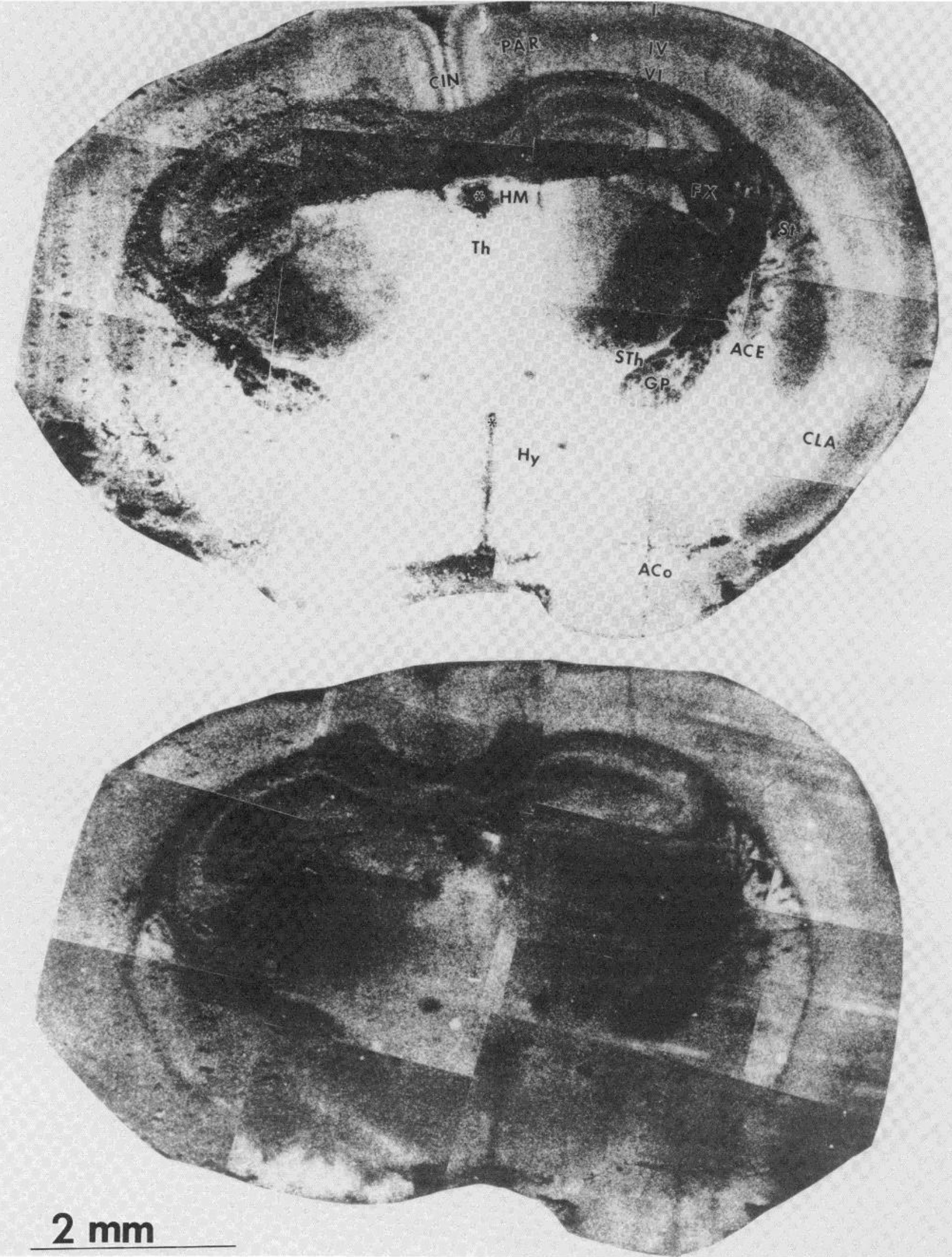

Figure 5. Darkfield autoradiograms of $\mu($ top $)$ and $\delta$ (bottom) binding sites in the telencephalon and diencephalon. $\mu$ sites were visualized using $1.7 \mathrm{nM}\left[{ }^{3} \mathrm{H}\right] \mathrm{DHM}$, and $\delta$ sites were visualized using $4.5 \mathrm{nM}\left[{ }^{3} \mathrm{H}\right] \mathrm{DADL}+2.5 \mathrm{nM}$ morphine. Note the high level of $\mu$ sites in the claustrum (CLA), central nucleus of the amygdala $(A C E)$, thalamus $(T h)$, and hypothalamus $(H y)$. A high number of both $\mu$ and $\delta$ sites is found in the medial habenular nucleus $(H M)$. ACo, cortical nucleus of the amygdala; $C I N$, cingulate cortex; FX, fornix; $G P$, globus pallidus; $P A R$, parietal cortex; $S t$, striatum; $S T h$, subthalamic nucleus; *, third ventricle; $I, I V$, and $V I$, laminae of the neocortex. 
finding of more enkephalin-immunoreactive fibers and terminals in the ventral than in the dorsal part of this area in the mouse (A. S. Moskowitz, J. C. Liebeskind, and L. L. Butcher, unpublished data) as well as in the rat (Hökfelt et al., 1977). Furthermore, although analgesia can be elicited by electrical stimulation of either the dorsal or ventral periaqueductal gray matter, only analgesia produced by stimulation of the ventral site is blocked by naloxone (Cannon et al., 1982) or by lesions of the bulbar raphe nuclei (Prieto et al., 1983).

In some areas, however, our quantitative results further extend those in the rat, where qualitative analysis allows only an approximation of the number of $\mu$ and $\delta$ sites seen (Goodman et al., 1980; Duka et al., 1981a, b). We observed a high ratio of $\mu / \delta$ binding in the medial habenular nucleus; low ratios of $\mu / \delta$ binding in the hippocampus and in the basal and lateral nuclei of the amygdala; and an equal ratio of $\mu / \delta$ binding in the interstitial nucleus of the stria terminalis and in the mesencephalic raphe nuclei.

Although some of the differences between our results and those of others (Goodman et al., 1980; Duka et al., 1981a, b) may be attributable to genuine species differences, some may be due to technical differences. Duka et al. used labeled DADL, whereas we used labeled DADL $+2.5 \mathrm{nM}$ morphine to visualize $\delta$ sites (similar to the protocol of Goodman et al.). Work by Pasternak and colleagues (Pasternak et al., 1980; Zhang and Pasternak, 1980, 1981; Wolozin and Pasternak, 1981) has provided evidence for the existence of a site $\left(\mu_{1}\right)$ that has a high affinity $\left(K_{D}<1.0 \mathrm{nM}\right)$ for all opiate alkaloids and opioid peptides. The binding of $\left[{ }^{3} \mathrm{H}\right] \mathrm{DADL}$ to this high affinity site as well as to the $\delta$ site is indicated by our nonsigmoidal competition curve, which shows that low concentrations of morphine displace a small percentage of $\left[{ }^{3} \mathrm{H}\right]$ DADL binding. Thus, we used $\left[{ }^{3} \mathrm{H}\right] \mathrm{DADL}$ plus a low concentration of morphine to eliminate the binding of $\left[{ }^{3} \mathrm{H}\right] \mathrm{DADL}$ to this high affinity site. Since the $K_{D}$ for opiate and enkephalin binding to the $\mu_{1}$ site is $<1 \mathrm{nM}$ (Wolozin and Pasternak, 1981), the $2.5 \mathrm{nM}$ morphine used in this study probably did displace almost all of the $\left[{ }^{3} \mathrm{H}\right] \mathrm{DADL}$ binding to $\mu_{1}$ sites. More importantly, both Goodman et al. (1980) and Duka et al. (1981a, b) did only a qualitative analysis of $\mu$ and $\delta$ binding, whereas we have quantified $\mu$ and $\delta$ site distributions for each area. Qualitative analysis is subject to error since the estimation of grain densities in an area is influenced by grain densities in surrounding areas.

The differential distribution of $\mu$ and $\delta$ sites may have functional correlates. For example, $\mu$-selective enkephalin analogues are more potent analgesics than $\delta$-selective peptides (Herz et al., 1978). This agrees with our findings that areas involved in the processing of nociceptive information, e.g., the dorsomedial thalamus, ventral periaqueductal gray matter, and laminae I and II of the spinal cord, are enriched in $\mu$ sites. $\delta$-specific enkephalins are more effective than $\mu$ agonists in eliciting limbic seizures (Urca et al., 1977; Frenk et al., 1978) and in facilitating reward behavior (Stein and Belluzzi, 1979). Limbic system structures, e.g., the olfactory tubercle, pyriform cortex, hippocampus, and basal, lateral, and cortical nuclei of the amygdala, are relatively enriched in $\delta$ sites.

In the neocortex the distribution of $\mu$ sites correlates with the distribution of extrinsic inputs, whereas the distribution of $\delta$ sites correlates with intrinsic connections. $\mu$ sites are concentrated in laminae I, IV, and VI, whereas $\delta$ sites are diffusely distributed throughout the laminae. Lamina IV receives inputs from specific sensory afferents, and laminae I and IV receive inputs from nonspecific afferents (e.g., Shepherd, 1979).

The administration of opiates and opioid peptides affects a variety of behaviors, including pain perception, cardiovascular functioning (Kokka et al., 1965; Laubie et al., 1974; Bellet et al., 1980; Holaday and Faden, 1980), food and water intake (Holtzman, 1975; Frenk and Rogers, 1979), thermoregulation (Clark, 1979), motor activity (Holtzman, 1974), learning and memory (Stein and Belluzzi, 1979), response to reward (Belluzzi and Stein, 1977; Stapleton et al., 1979), seizure activity (Urca et al., 1977; Frenk et al., 1978), and hormone release (Firemark and Weitzman, 1979; Gibson et al., 1979; Gold et al., 1979; Ieiri et al., 1979; Meites et al., 1979; Van Vugt et al., 1979). By suggesting anatomical sites that may mediate these effects, our results should facilitate the design of pharmacological and behavioral experiments to test hypotheses generated by the findings above. Such work should give insights into the physiological roles played by the endogenous opioid system.

\section{References}

Atweh, S. F., and M. J. Kuhar (1977a) Autoradiographic localization of opiate receptors in rat brain. I. Spinal cord and lower medulla. Brain Res. 124: 53-67.

Atweh, S. F., and M. J. Kuhar (1977b) Autoradiographic localization of opiate receptors in rat brain. II. The brain stem. Brain Res. 129: 1-12.

Atweh, S. F., and M. J. Kuhar (1977c) Autoradiographic localization of opiate receptors in rat brain. III. The telencephalon. Brain Res. 134: 393-405.

Bellet, M. J., J. L. Elghozi, P. Meyer, M. G. Pernollet, and H. Schmitt (1980) Central cardiovascular effects of narcotic analgesics and enkephalins in rats. Br. J. Pharmacol. 71: 365-369.

Belluzzi, J., and L. Stein (1977) Enkephalins may mediate euphoria and drive-reduction reward. Nature 266: 556-558.

Cannon, J. T., G. J. Prieto, A. Lee, and J. C. Liebeskind (1982) Evidence for opioid and nonopioid forms of stimulationproduced analgesia in the rat. Brain Res. 243: 315-321.

Carroll, B. J., and P. T. Sharp (1972) Monoamine mediation of the morphine-induced activation of mice. Br. J. Pharmacol. 46: $124-139$.

Chang, K. -J., B. R. Cooper, E. Hazum, and P. Cautrecasas (1979) Multiple opiate receptors: Different regional distribution in the brain and differential binding of opiates and opioid peptides. Mol. Pharmacol. 16: 91-104.

Clark. W. G. (1979) Influence of opioids on central thermoregulatory mechanisms. Pharmacol. Biochem. Behav. 10: 609-613.

Della Bella, D., F. Casacci, and A. Sassi (1978) Opiate receptors: Different ligand affinity in various brain regions. Adv. Biochem. Psychopharmacol. 18: 271-277.

Duka, T., P. Schubert, M. Wüster, R. Stoiber, and A. Herz (1981a) A selective distribution pattern of different opiate receptors in certain areas of rat brain as revealed by in vitro autoradiography. Neurosci. Lett. 21: 119-124. 
Duka, T., M. Wüster, P. Schubert, R. Stoiber, and A. Herz (1981b) Selective localization of different types of opiate receptors in hippocampus as revealed by in vitro autoradiography. Brain Res. 205: 181-186.

Firemark, H. M., and R. E. Weitzman (1979) Effects of betaendorphin, morphine and naloxone on arginine vasopressin secretion and the electroencephalogram. Neuroscience 4: 1895-1902.

Frenk, II., and G. II. Rogers (1979) The supressant effects of naloxone on food and water intake in the rat. Behav. Neural Biol. 26: 23-40.

Frenk, H., G. Urca, and J. C. Liebeskind (1978) Epileptic properties of leucine- and methionine-enkephalin: Comparison with morphine and reversibility by naloxone. Brain Res. 147: $327-337$.

Gibson, A., M. Ginsburg, M. Hall, and S. L. Hart (1979) The effects of opiate receptor agonists and antagonists on the stress-induced secretion of corticosterone in mice. Br. J. Pharmacol. 65: 139-146.

Gillan, M. G. C., H. W. Kosterlitz, and S. J. Paterson (1980) Comparison of the binding characteristics of tritiated opiates and opioid peptides. Br. J. Pharmacol. 70: 481-490.

Gold, M. S., D. E. Redmond, Jr., and R. K. Donakedia (1979) The effects of opiate agonist and antagonist on serum prolactin in primates: Possible role for endorphins in prolactin secretion. Endocrinology 105: 284-289.

Goodman, R. R., S. H. Snyder, M. J. Kuhar, and W. S. Young, III (1980) Differentiation of delta and mu opiate receptor localizations by light microscopic autoradiography. Proc. Natl. Acad. Sci. U. S. A. 77: 6239-6243.

Goodman, R. R., M. J. Kuhar, and A. S. Moskowitz (1982) Light microscopic autoradiography of $\mathrm{mu}$ and delta opiate binding sites in mouse CNS. Soc. Neurosci. Abstr. 8: 221.

Herkenham, M., and C. B. Pert (1980) In vitro autoradiography of opiate receptors in rat brain suggests loci of "opiatergic" pathways. Proc. Natl. Acad. Sci. U. S. A. 77: 5532-5536.

Herz, A., J. Bläsig, H. M. Emrich, C. Cording, S. Píree, A. Kölling, and D. V. Zerssen (1978) Is there some indication from behavioral effects of endorphins for their involvement in psychiatric diseases? Adv. Biochem. Psychopharmacol. 18: 333-339.

Hökfelt, T., R. Elde, O. Johansson, L. Terenius, and L. Stein (1977) The distribution of enkephalin-immunoreactive cell bodies in the rat central nervous system. Neurosci. Lett. 5 : 25-31.

Holaday, J. W., and A. I. Faden (1978) Naloxone reversal of endotoxic hypotension suggests role of endorphins in shock. Nature 275: 450-451.

Holtzman, S. G. (1974) Behavioral effects of separate and combined administration of naloxone and $d$-amphetamine. J. Pharmacol. Exp. Ther. 189: 51-60.

Iloltzman, S. G. (1975) Effects of narcotic antagonists on fluid intake in the rat. Life. Sci. 16: 1465-1470.

Hughes, J. (1975) Isolation of an endogenous compound from the brain with pharmacological properties similar to morphine. Brain Res. 88: 295-308.

Hughes, J., T. Smith, H. W. Kosterlitz, L. Fothergill, B. Morgan, and H. R. Morris (1975) Identification of two related pentapeptides from the brain with potent opiate agonist activity. Nature 258: 577-579.

Ieiri, T., H. T. Chen, and J. Meites (1979) Effects of morphine and naloxone on serum levels of luteinizing hormone and prolactin in prepubertal male and female rats. Neuroendocrinology 29: 288-292.

Kokka, N., H. W. Elliot, and E. L. Way (1965) Some effects of morphine on respiration and metabolism of rats. J. Pharmacol. Exp. Ther. 148: 386-392.

Kuhar, M. J., C. B. Pert, and S. H. Snyder (1973) Regional distribution of opiate receptor binding in monkey and human brain. Nature 245: 447-451.

Kuschinsky, K., and O. Hornykiewicz (1974) Effects of morphine on striatal dopamine metabolism: Possible mechanism of its opposite effect on locomotor activity in rats and mice. Eur. J. Pharmacol. 26: 41-50.

Laubie, M., H. Schmitt, J. Canellas, J. Roquebert, and P. Demichel (1974) Centrally mediated bradycardia and hypotension elicited by narcotic analgesics dextromoramide and fentanyl. Eur. J. Pharmacol. 28: 66-75.

Leslie, F. M., C. Chavkin, and B. M. Cox (1980) Opioid binding properties of brain and peripheral tissues. Evidence for heterogeneity in opioid ligand binding sites. J. Pharmacol. Exp. Ther. 214: 395-402.

Lewis, M. E., M. Mishkin, E. Bragin, R. M. Brown, C. B. Pert, and A. Pert (1981) Opiate receptor gradients in monkey cerebral cortex: Correspondence with sensory processing hierarchies. Science 211: 1166-1169.

Li, C. H., and D. Chung (1976) Isolation and structure of an untriankontapeptide with opiate activity from camel pituitary glands. Proc. Natl. Acad. Sci. U. S. A. 73: 1145-1148.

Lord, J. A. H., A. A. Waterfield, J. Hughes, and H. W. Kosterlitz (1977) Endogenous opioid peptides: Multiple agonists and receptors. Nature 267: 495-499.

Martin, W. R., C. G. Eades, J. A. Thompson, R. E. Huppler, and P. E. Gilbert (1976) The effects of morphine- and nalorphine-like drugs in the nondependent and morphine-dependent chronic spinal dog. J. Pharmacol. Exp. Ther. 197: 517532 .

Meites, J., J. E. Bruni, D. A. Van Vugt, and A. F. Smith (1979) Relation of endogenous opioid peptides and morphine to neuroendocrine functions. Life Sci. 24: 1325-1336.

Pasternak, G. W., R. Goodman, and S. H. Snyder (1975a) An endogenous morphine-like factor in mammalian brain. Life Sci. 16: 1765-1769.

Pasternak, G. W., H. A. Wilson, and S. H. Snyder (1975b) Differential effects of protein modifying reagents on receptor binding of opiate agonists and antagonists. Mol. Pharmacol. 11: $340-351$.

Pasternak, G. W., S. R. Childers, and S. H. Snyder (1980) Naloxazone, a long-lasting opiate antagonist: Effects on analgesia in intact animals and on opiate receptor binding in vitro. J. Pharmacol. Exp. Ther. 214: 455-462.

Pearson, L., L. Brandeis, E. Simon, and J. Miller (1980) Radioautography of binding of tritiated diprenorphine to opiate receptors in the rat. Life Sci. 26: 1047-1052.

Pert, C. B., and S. H. Siryder (1973) Opiate receptor: Demonstration in nervous tissue. Science 179: 1011-1014.

Pert, C. B., D. Aposhian, and S. H. Snyder (1974) Phylogenetic distribution of opiate receptor binding. Brain Res. 75: 356361.

Pert, C. B., M. J. Kuhar, and S. H. Snyder (1975) Autoradiographic localization of the opiate receptor in rat brain. Life Sci. 16: 1849-1854.

Pert, C. B., M. J. Kuhar, and S. H. Snyder (1976) Opiate receptor: Autoradiographic localization in rat brain. Proc. Natl. Acad. Sci. U. S. A. 73: 3729-3733.

Prieto, G. J., J. T. Cannon, and J. C. Liebeskind (1983) N. raphe magnus lesions disrupt stimulation-produced analgesia from ventral but not dorsal midbrain areas in the rat. Brain Res. 261: 53-57.

Robson, L. E., and H. W. Kosterlitz (1979) Specific protection of the binding sites of D-Ala ${ }^{2}$-D-Leu ${ }^{5}$-enkephalin (deltareceptors) and dihydromorphine (mu-receptors). Proc. R. Soc. Lond. 205: 425-432.

Schulz, R., M. Wüster, H. Krenss, and A. Herz (1980) Selective development of tolerance without dependence in multiple opiate receptors of mouse vas deferens. Nature 285: 242-243. 
Schulz, R., M. Wüster, P. Rubini, and A. Herz (1981) Functional opiate receptors in the guinea-pig ileum: Their differentiation by means of selective tolerance development. J. Pharmacol. Exp. Ther. 219: 547-550.

Shepherd, G. M. (1979) The Synaptic Organization of the Brain, pp. 308-387, Oxford University Press, New York.

Sidman, R. L., J. B. Angevine, Jr., and E. Taber Pierce (1971) Atlas of the Mouse Brain and Spinal Cord, Harvard University Press, Cambridge, MA.

Simantov, R., and S. H. Snyder (1976) Morphine-like peptide in mammalian brain: Isolation, structure elucidation, and interactions with the opiate receptor. Proc. Natl. Acad. Sci. U. S. A. 73: 2515-2519.

Simon, E. J., J. M. Hiller, and I. Edelman (1973) Stereospecific binding of the potent narcotic analgesic $\left[{ }^{3} \mathrm{H}\right]$-etorphine to rat brain homogenates. Proc. Natl. Acad. Sci. U. S. A. 70: 1947-1949.

Stapleton, J. M., M. D. Lind, V. J. Merriman, M. A. Bozarth, and L. D. Reid (1979) Affective consequences and subsequent effects on morphine self-administration of $d$-Ala ${ }^{2}$-methionine enkephalin. Physiol. Psychol. 7: 146-152.

Stein, L., and J. D. Belluzzi (1979) Brain endorphins: Possible role in reward and memory function. Fed. Proc. 38: 24682472.

Terenius, L. (1973) Stereospecific interaction between narcotic analgesics and a synaptic plasma fraction of rat cerebral cortex. Acta Pharmacol. Toxicol. 32: 317-320

Unnerstall, J. R., D. L. Niehoff, M. J. Kuhar, and J. M. Palacios (1982) Quantitative receptor autoradiography using $\left[{ }^{3} \mathrm{H}\right] \mathrm{Ul}-$ trofilm: Application to multiple benzodiazepine receptors. $\mathrm{J}$. Neurosci. Methods 6: 59-73.

Urca, G., H. Frenk, J. C. Liebeskind, and A. N. Taylor (1977) Morphine and enkephalin: Analgesic and epileptic properties. Science 197: 83-86.

Van Vugt, H. T., J. F. Bruni, P. W. Sylvester, H. T. Chen, T. Ieiri, and J. Meites (1979) Interaction between opiates and hypothalamic dopamine on prolactin release. Life Sci. 24: 2361-2368.

Wolozin, B. L., and G. W. Pasternak (1981) A classification of multiple morphine and enkephalin binding sites in the central nervous system. Proc. Natl. Acad. Sci. U. S. A. 78: 61816185.

Young, W. S., III, and M. J. Kuhar (1979) A new method for receptor autoradiography: ${ }^{3} \mathrm{H}$-opioid receptors in rat brain. Brain Res. 179: 255-270.

Zhang, A. -Z., and G. W. Pasternak (1980) Mu- and deltaopiate receptors: Correlation with high and low affinity opiate binding sites. Eur. J. Pharmacol. 67: 323-324.

Zhang, A. -Z., and G. W. Pasternak (1981) Opiates and enkephalins: $\Lambda$ common site mediates their analgesic actions in rats. Life Sci. 29: 843-851. 